anticoagulant therapy

antiplatelet therapy

crescent formation

hematuria hypergammaglobulinemia

proteinuria

rapidly progressive glomerulonephritis renal failure

\title{
Rapidly Progressive Glomerulonephritis in Children: A Report of Thirteen Cases and a Review of the Literature
}

\author{
ROBERT J. CUNNINGHAM, III $^{37}$, MASON GILFOIL, TITO CAVALLO, BEN H. BROUHARD, \\ LUTHER B. TRAVIS, MICHAEL BERGER, AND THOMAS PETRUSICK
}

Departments of Pediatrics and Pathology, Divisions of Nephrology and Renal Immunopathology, The University of

Texas Medical Branch, Galveston, Texas USA 77550

\section{Summary}

The clinical course and outcome of rapidly progressive glomerulonephritis (RPGN) of variable etiology are not well defined in children. The present investigation reports on the clinical characteristics, the course and outcome, as well as the results of treatment of 13 children with apparent postinfectious RPGN. Three of 7 patients with documented streptococcal RPGN and 3 of 6 patients with RPGN of nonstreptococcal etiology progressed to chronic renal failure. In some patients, anticoagulant and antiplatelet therapy appear to have improved survival. The severity of crescent formation, not the presumable etiology, appears to be a reliable prognosticator.

\section{Speculation}

A number of disease processes can result in renal damage of sufficient severity to cause crescent formation. The induction, resolution, or progression of crescents to sclerosis may be influenced by anticoagulant therapy.

Rapidly progressive glomerulonephritis (RPGN), recognized by Ellis (13) and further defined by Heptinstall (21), was first described as an unusual form of acute glomerulonephritis (AGN) which progressed to renal failure, in contrast to the typical course of rapid resolution. A clinical feature which seemed to separate RPGN from AGN was a period of prolonged oliguria.

It is now known that the renal histology in RPGN is characterized by crescent formation with or without endocapillary proliferation of cells.

RPGN has been seen in association with a number of systemic diseases, including anaphylactoid purpura, systemic lupus erythematosus, Goodpasture's syndrome, mixed cryoglobulinemia, and polyarteritis nodosa $(13,24)$. Patients with serologic evidence of poststreptococcal AGN (PSAGN) or with biopsy proven membranoproliferative glomerulonephritis may also exhibit a form of RPGN (22).

Despite the fact that this entity has been recognized for over 30 years, there is little evidence that any mode of therapeutic intervention has altered its outcome. A recent work in this respect has been with anticoagulant therapy, and there is some experimental evidence of its efficacy (30), although this remains controversial $(6,7)$. There have also been some uncontrolled patients studies which lend support to the use of these drugs (8), but their effectiveness is still in question (14).

The purpose of this paper is to present our experience with RPGN in children; emphasis will be placed on the clinical characteristics at initial presentation. Current concepts of etiology, particularly of its influence on prognosis, and of the use of anticoagulant therapy are reviewed.

\section{MATERIALS AND METHODS}

A retrospective analysis was performed on all pediatric patients seen at The University of Texas Medical Branch at Galveston since 1963 who had a rapid deterioration of renal function in association with an apparent acute onset of glomerulonephritis. Specifically, patients were included in the study population only if they met all of the following requirements: 1) documented glomerulonephritis with red blood cells casts present in the urine or the presence of red blood cells in the urine in association with proteinuria (by Labstix); 2) kidneys of normal or near-normal size, as determined by iv pyelography or tomography; 3 ) evidence of increasing azotemia (blood urea nitrogen, creatinine) over a maximum period of four months; 4) a renal biopsy specimen in which a substantial percentage of glomeruli were involved. This involvement included variable proliferation of cells in Bowman's space, crescents circumscribing in arc of $180^{\circ}$ or more or glomerular obsolescence.

Laboratory data, obtained by standard hospital procedures when the patient was first evaluated, were used in the tabulation of data. Oliguria was defined as a urine output of less than 200 $\mathrm{cc} / \mathrm{m}^{2} /$ day. Renal biopsies were performed 2 to 16 weeks after the onset of symptoms by a technique which has been described previously (11).

Sections for light microscopy were fixed in $2 \%$ paraformaldehyde and $2-\mu \mathrm{m}$ sections were cut and stained with 2 or more of the following: periodic acid-Schiff, methenamine silver, hematoxylin and eosin, and Gomori's trichrome. For immunofluorescence, tissues were snap-frozen in $-70^{\circ}$ isopentane; then $4-\mu \mathrm{m}$ sections were cut and stained with monospecific antisera to human immunoglobulins and ocmplement $\left(\mathrm{C}_{3}\right)$. Sections for electron microscopy were fixed in $2 \%$ paraformaldehyde and embedded in epoxy resin (Epon 812). Silver to gold sections cut with an ultramicrotome were stained with uranyl acetate and lead citrate and examined in a Phillip 200 EM electron microscope.

\section{RESULTS}

The demographic data and clinical characteristics at initial presentation, as well as the etiologies and the current status of the patients in our series are summarized in Tables 1 and 2. There were nine males and four females, most of whom were in the early teenage years. Ten of 13 children presented with edema, and 11 also had the onset of gross hematuria 1 to 4 weeks prior to seeking medical attention. Eleven of the patients were hypertensive when first evaluated, and all were azotemic. All but two of the patients were first thought to have PSAGN; patients 4 and 6 had histories suggestive of a more chronic process and were thought to have a form of chronic glomerulonephritis. An unusual feature for a patient with acute glomerulonephritis was the degree of anemia. Nine patients had a hemoglobin concentration of less than $9.0 \mathrm{~g}$ 
Table 1. Summary of clinical characteristics of patients with rapidly progressive glomerulonephritis

\begin{tabular}{|c|c|c|c|c|c|c|c|c|c|c|c|}
\hline Patient & $\begin{array}{l}\text { Age } \\
\text { (yr) }\end{array}$ & Sex & $\begin{array}{c}\text { Blood pres- } \\
\text { sure (mm } \\
\text { Hg) }\end{array}$ & Hematuria & $\begin{array}{l}\text { Total pro- } \\
\text { tein (gm/ } \\
\text { dl) }\end{array}$ & $\begin{array}{c}\gamma \text {-globulin } \\
(\mathrm{gm} / \mathrm{dl})\end{array}$ & $\begin{array}{l}\text { Protein- } \\
\text { uria }^{1}\end{array}$ & $\begin{array}{c}\text { Blood urea } \\
\text { nitrogen } \\
(\mathrm{mg} / \mathrm{dl})\end{array}$ & $\begin{array}{c}\text { Creatinine } \\
(\mathrm{mg} / \mathrm{dl})\end{array}$ & Oliguria & $\begin{array}{l}\text { Hemoglobin } \\
(\mathrm{gm} / \mathrm{dl})\end{array}$ \\
\hline 1 & 4 & $\mathbf{M}$ & $130 / 90$ & Gross & $\mathrm{ND}^{2}$ & ND & $4+$ & 212 & 3.2 & No & 7.2 \\
\hline 2 & 8 & $\mathbf{M}$ & $160 / 120$ & Gross & 4.5 & 0.20 & $4+$ & 59 & 1.0 & No & 8.7 \\
\hline 3 & 13 & $\mathbf{M}$ & $140 / 100$ & Countless & 5.0 & 0.9 & $4+$ & 86 & 2.0 & No & 6.1 \\
\hline 4 & 11 & $F$ & $180 / 110$ & Microscopic & 5.0 & 0.6 & $4+$ & 32 & 1.9 & No & $10.0-8.4$ \\
\hline 5 & 12 & $M$ & $130 / 86$ & Gross & 4.4 & 1.65 & $4+$ & 112 & 10.0 & Yes & 11.0 \\
\hline 6 & 13 & $\mathbf{M}$ & $180 / 120$ & Gross & 9.7 & 3.85 & $3+$ & 150 & 11.7 & No & 6.3 \\
\hline 7 & 13 & $\mathrm{~F}$ & $170 / 110$ & Gross & 7.5 & 2.0 & $3+$ & 165 & 20.5 & Yes & 6.9 \\
\hline 8 & 12 & $\mathrm{~F}$ & $130 / 80$ & Gross & 6.9 & 2.5 & $4+$ & 35 & 5.1 & No & $8.3-6.9$ \\
\hline 9 & 13 & $\mathbf{M}$ & $190 / 110$ & Gross & 5.4 & 1.7 & $3+$ & 138 & 2.5 & No & $12.3-7.6$ \\
\hline 10 & 11 & $\mathbf{M}$ & $130 / 110$ & Gross & 6.0 & 0.7 & $3+$ & 123 & 2.8 & No & 12.4 \\
\hline 11 & 8 & M & $130 / 110$ & Gross & 5.8 & 1.2 & $4+$ & 144 & 6.3 & Yes & 5.0 \\
\hline 12 & 5 & $M$ & $140 / 110$ & Gross & 4.3 & 1.0 & $3+$ & 60 & 5.5 & Yes & 6.1 \\
\hline 13 & 13 & $\mathrm{~F}$ & $142 / 93$ & Gross & 7.5 & 2.5 & $4+$ & 101 & 2.3 & No & 8.4 \\
\hline
\end{tabular}

'Labstix (Ames Company, Elkhart, IN)

${ }^{2} \mathrm{ND}$, not done.

Table 2. Summary of pathological characteristics and outcome of patients with rapidly progressive glomerulonephritis

\begin{tabular}{|c|c|c|c|c|c|c|}
\hline Patient & $\mathrm{Yr}$ & $\begin{array}{l}\text { No. of } \\
\text { glomeruli }\end{array}$ & $\begin{array}{c}\% \text { of glomeruli } \\
\text { obsolescent or } \\
\text { crescents of } 180^{\circ *}\end{array}$ & Disease & Treatment & Status \\
\hline 1 & 1963 & 36 & 47 & PSAGN & $\mathrm{D}^{2}$ & $\begin{array}{l}\text { Blood urea nitrogen } 22 \text {, proteinuria, } 1+ \\
(1974)\end{array}$ \\
\hline 2 & 1966 & 30 & 50 & Idiopathic & AZO & Transplant (1973) \\
\hline 3 & 1967 & 24 & 10 & PSAGN & AZO, $P$ & Two yr/died \\
\hline 4 & 1968 & 56 & 33 & MPGN & & $\mathrm{GFR}^{3} 38$, proteinuria $1+(1975)$ \\
\hline 5 & 1968 & 9 & 77 & Idiopathic & $\mathrm{AZO}, \mathrm{P}, \mathrm{CY}, \mathrm{D}$ & Transplant, 3 months/died, 15 months \\
\hline 6 & 1969 & 10 & 70 & PSAGN & $\mathrm{CY}, \mathrm{D}$ & 9 months/died \\
\hline 7 & 1971 & 17 & 64 & PSAGN & $\mathrm{AZO}, \mathrm{H}, \mathrm{CH}, \mathrm{D}$ & 6 months/died \\
\hline 8 & 1973 & 15 & 40 & MPGN & $\mathrm{AZO}, \mathrm{P}, \mathrm{CH}, \mathrm{D}$ & $\mathrm{GFR}^{3} 57$ (1974) \\
\hline 9 & 1973 & 14 & 43 & PSAGN & $\mathrm{AZO}, \mathrm{P}, \mathrm{H}, \mathrm{WA}, \mathrm{CH}, \mathrm{D}$ & Well; 15 glomeruli obsolescent \\
\hline 10 & 1973 & 6 & 83 & PSAGN & $\mathrm{AZO}, \mathrm{P}, \mathrm{H}, \mathrm{CH}, \mathrm{D}$ & $\begin{array}{l}\text { Proteinuria } 1+; 33 \% \text { glomeruli obsoles- } \\
\text { cent }\end{array}$ \\
\hline 11 & 1976 & 16 & 88 & Idiopathic & AZO, P, H, DIP, D & Creatinine $1.4 \mathrm{mg} / \mathrm{dl}$ \\
\hline 12 & 1976 & 5 & 100 & Idiopathic & $\mathrm{D}$ & Died 12 months \\
\hline 13 & 1976 & 11 & 82 & PSAGN & $\mathrm{AZO}, \mathrm{P}, \mathrm{H}, \mathrm{DIP}, \mathrm{D}$ & Creatinine $1.2 \mathrm{mg} / \mathrm{dl}$ (6 months) \\
\hline
\end{tabular}

${ }^{1}$ Rounded off to nearest whole percentage.

${ }^{2}$ Abbreviations: D, dialysis during acute phase; AZO, azothiprine; CY, cylcophosphamide; CH, cyprohepatadine; H, heparin; $\mathrm{P}$, prednisone; WA, warfarin; DIP, dipyridamole.

${ }^{3} \mathrm{ml} / \mathrm{min} / \mathrm{m}^{2}$ (normal $\left.60-80\right)$

$\%$ in the absence of any source of external blood loss other than gross hematuria. Reticulocyte counts ranged from $2.0-7.0 \%$, peripheral blood smears showed normal red blood cell morphology, and serum haptoglobin concentration was normal in the two patients in which it was measured. Four patients presented with oliguria; of these, three subsequently developed chronic renal failure. Eight patients had a relative hypergammaglobulinemia with $\gamma$ globulin fraction accounting for $20-50 \%$ of the total serum protein.

Eleven of the patients were biopsied within 6 weeks following the onset of symptoms. Salient features are summarized in Table 2. Immunofluorescent studies were performed in biopsies from nine patients; all showed granular deposits of $\operatorname{IgG}$ and $C_{3}$ of varying intensity (trace to $3+$ ) along glomerular capillary loops. All specimens also demonstrated positive staining for fibrin/fibrinogen, which tended to be localized almost exclusively in the glomerular crescents.

Possible etiologies of the RPGN are shown in Table 2. Seven patients had strong evidence of a preceding streptococcal pharyngitis. Additional criteria by which the diagnosis of an antecedent streptococcal infections was confirmed are summarized in Table 3.
Two of the patients in this series had membranoproliferative glomerulonephritis (MPGN), with subendothelial deposit (type I) diagnosed 4 to 12 months after onset.

No associated systemic disease or infection could be documented in 4 patients. Because they exhibited little (patients 11 and 12) or no (patients 2 and 5) intracapillary proliferation, they were considered as instances of idiopathic RPGN (Table 2).

Three of eight patients with documented APSGN progressed to renal failure, as did three patients with idiopathic RPGN. Both patients with MPGN are currently doing well with slightly diminished glomerular filtration rates but persistent proteinuria 3 and 8 years later.

A wide variety of therapeutic regimens were used in the treatment of these patients. Since 1971, heparin has also been used. Of the six patients treated with anticoagulants, only one progressed to renal failure; of the seven patients not treated with anticoagulants, five progressed to renal insufficiency. The patient who died despite anticoagulant therapy had oliguria for two weeks prior to initiation of therapy (urine outputs ranged from 90 to $150 \mathrm{cc} /$ day); following institution of therapy, the output increased to $1200 \mathrm{cc} /$ day. However, after one month of hospitalization, the patient refused further dialysis or therapy and was discharged. She died 
Table 3. Criteria used to establish streptococcal etiology of patients with rapidly progressive glomerulonephritis

\begin{tabular}{|c|c|c|c|c|c|c|c|}
\hline Patient & $\mathrm{Yr}$ & History of infection & Culture & $\mathrm{ASO}^{\prime}$ & Other & $\mathrm{C}_{3}+$ & Biopsy \\
\hline 1 & 1973 & $\begin{array}{l}\text { Cervical adenitis } 1 \mathrm{wk} \\
\text { prior to onset of } \\
\text { edema }\end{array}$ & & 625 & & & $\begin{array}{l}\text { 1. Mesangial hypercellu- } \\
\text { larity, neutrophils }\end{array}$ \\
\hline 3 & 1967 & $\begin{array}{l}\text { Pharyngitis, } 2 \text { wks } \\
\text { prior to presentation }\end{array}$ & $\begin{array}{l}\text { GR. A B hemo- } \\
\text { lytic strep } \\
\text { (treated } 50 \text { with } \\
\text { penicillin) }\end{array}$ & 50 & & Normal & $\begin{array}{l}\text { 1. Endocapillary and hy- } \\
\text { percellularity, neutro- } \\
\text { phils; } 2 \text {. IgG, IgM } C_{3} \\
\text { in granular pattern; } 3 \text {. } \\
\text { Numerous subepithe- } \\
\text { lial deposits (humps) }\end{array}$ \\
\hline 6 & 1969 & $\begin{array}{l}\text { Pharyngitis, } 2 \text { wks } \\
\text { prior to presentation }\end{array}$ & & $\frac{10 \text { days }}{50833}$ & & & $\begin{array}{l}\text { 1. Lobular sclerosis, re- } \\
\text { sidual mesangial hy- } \\
\text { percellularity }\end{array}$ \\
\hline 7 & 1971 & $\begin{array}{l}\text { Pharyngitis, } 1 \text { wk prior } \\
\text { to onset of gross he- } \\
\text { maturia }\end{array}$ & & $\begin{array}{l}\frac{1 \mathrm{wk}}{625833} \\
\text { Biopsy, } 8 \text { wks }\end{array}$ & & $\frac{2 \mathrm{wks}}{33 \quad 90}$ & $\begin{array}{l}\text { 1. Lobular sclerosis and } \\
\text { basement membrane } \\
\text { thickening; }{ }^{2} \text {. Discrete } \\
\text { intramembranous and } \\
\text { subendothelial depos- } \\
\text { its. }\end{array}$ \\
\hline 9 & 1973 & $\begin{array}{l}\text { Pharyngitis, } 1 \mathrm{wk} \text { prior } \\
\text { to presentation im- } \\
\text { petigo } 3 \text { wks prior to } \\
\text { presentation }\end{array}$ & $\begin{array}{l}\text { GR. A strep } \\
\text { (treated with } \\
\text { penicillin) }\end{array}$ & 330 & & Normal & $\begin{array}{l}\text { 1. Mesangial hypercellu- } \\
\text { larity; } 2 . \mathrm{IgG}, \mathrm{IgM}, \mathrm{C}_{3} \\
\text { in granular pattern. }\end{array}$ \\
\hline 10 & 1973 & $\begin{array}{l}\text { Pharyngitis, } 1 \text { month } \\
\text { before onset of } \\
\text { edema (treated with } \\
\text { penicillin) }\end{array}$ & & 125 & $\begin{array}{l}\text { AHA } 256 \\
(1-128) \\
\text { anti-DNase } \\
40(0-10)\end{array}$ & & $\begin{array}{l}\text { 1. Mesangial hypercellu- } \\
\text { larity; } 2 . \operatorname{IgG}, \mathrm{C}_{3} \text { in } \\
\text { granular pattern. }\end{array}$ \\
\hline 13 & 1976 & $\begin{array}{l}\text { Pharyngitis, } 3 \text { wks } \\
\text { prior to admission }\end{array}$ & & 1250 & AHA 4096 & $83 \mathrm{mg} / \mathrm{dl}$ & $\begin{array}{l}\text { 1. Hypercellularity; } 2 \text {. } \\
\text { IgG, } \mathrm{C}_{3} \text { in granular } \\
\text { pattern; } 3 \text {. electron mi- } \\
\text { croscopy subepithelial } \\
\text { humps }\end{array}$ \\
\hline
\end{tabular}

${ }^{1}$ Todd Units. AHA, Antihyaluronidase, normal (1-128) anti-DNAse, normal (0-10) $+\mathrm{C}_{3}$ normal $(70-150 \mathrm{mg} / \mathrm{dl})$.

${ }^{2}$ Biopsies performed 8 wks after clinical presentation.

at home 6 months later. Other patients on heparin therapy also had substantial increases in urine output and decreases in serum creatinine.

\section{DISCUSSION}

The difficulty in comparing our experience with RPGN with that of other centers is the lack of a uniform definition of this entity. Early reports were based on autopsy material. Other reports equated the presence of glomerular epithelial crescents with clinical progression to terminal renal failure (13). Recent studies analyzing renal biopsy material clarified that the presence of crescents does not always portend progressive renal failure(16). Habib included patients in the RPGN category only when $80 \%$ of the glomeruli had crescents occupying an arc of greater than $180^{\circ}$. The renal mortality rate was $100 \%$. In contrast, Anand et al. were less stringent, requiring that there be crescents in only $20 \%$ of the glomeruli for the diagnosis of RPGN to be established; the renal mortality rate in their series was only $55 \%$. Another complicating factor is that some investigators will exclude patients with an underlying systemic disease, whereas others include these patients but exclude those with a streptococcal etiology (22).

All of our patients had hematuria and proteinuria, features comparable to those compiled from other series $(1,2,5,8,9,10$, $12,15,20,22,23,25,27,29,33,36)$. In contrast to adults, who characteristically are normotensive when they present with RPGN $(2,23) 85 \%$ of our patients and $80 \%$ of the pediatric patients reported elsewhere presented with hypertension. Thus, the clinical picture of pediatric patients with RPGN is in general that of an acute postinfectious glomerulonephritis with a presenting complaint of gross hematuria. In 10 of 13 patients in our series, edema also occurred in association with hypertension.

Two laboratory studies which may be helpful in distinguishing patients with RPGN from those with an otherwise uncomplicated $\mathrm{AGN}$ are the hemoglobin concentration and the serum protein electrophoresis. Nine of the patients in our series had hemoglobins of less than $9.0 \mathrm{mg} / \mathrm{d}$, a degree of anemia that is unusual for acute glomerulonephritis. Another distinguishing feature of our RPGN patients is the relative hypergammaglobulinemia, particularly when seen in association with heavy proteinuria. Eight patients had $\gamma$ globulin fractions which accounted for greater than $20 \%$ of the total serum protein concentration. In four of these, the $\gamma$ globulin fraction accounted for $33 \%$ of the total serum proteins. Although this observation has been made previously in adults with RPGN (19) there is no explanation as to why this occurs.

Since the study by Leonard et al. (25) of RPGN in adults, it has been accepted that patients with a streptococcal etiology have a considerably better prognosis. Our data indicate that this concept may not be applicable to the pediatric population. Whereas there was an $80 \%$ spontaneous remission rate in Leonard's series of patients with poststreptococcal RPGN, $43 \%$ of our patients subsequently developed renal failure. Of these 3 patients with PSAGN who progressed to chronicity, one exhibited severe crescent formation limited to $10 \%$ of the glomeruli (patient 3). Biopsy sampling may not have been representative in this patient. Of those 
patients with evidence of prior streptococcal infection, three of the four who did not receive anticoagulants died, whereas all three who received heparin as part of their therapy have near-normal renal function (Table 2). Progression of PSAGN to renal insufficiency has also been reported by others. Thus, documentation of a prior streptococcal infection does not necessarily imply that the RPGN will spontaneously resolve.

Interestingly, all patients in our study with documented poststreptococcal disease had a history of pharyngitis; none had a history of impetigo alone, which accounts for $50-60 \%$ of the APSGN seen in our hospital $(28,30)$. There is some evidence that local conditions at the site of infection may influence the antigens produced and the responses of circulating antibodies (31). Thus, it is tempting to speculate that streptococcal infection of the skin may not lead to RPGN. MPGN was detected in two of the patients in our study population. In contrast to our patients who had MPGN with subendothelial deposits, dense deposit disease is more commonly associated with crescent formation (16). As outlined by Habib, et al. (18), these patients often present with gross hematuria, hypertension, and severe anemia. The only surprising feature of our patients is their outcome; both of our patients have persistent proteinuria (approximately $1 \mathrm{~g} / 24 \mathrm{hr}$ ) without the nephrotic syndrome, and glomerular filtration rates are still close to normal 3 to 8 years later, respectively. In the largest series reported to date, Habib et al. described 16 children with MPGN who presented with epithelial crescents when first biopsied. Of these 16 patients, 15 progressed to renal failure, most of them within 3 years (18) In contrast, the two patients in our series have continued to improve as evidenced by decreasing proteinuria and increasing glomerular filtration rates.

Because the pathogenesis of RPGN is poorly understood, a rational approach to therapy is difficult. Immunofluorescent studies of biopsy material reveal that the initial insult may be due to the formation of immune complexes, in which case a granular distribution of antibiodies and complement as well as fibrinogen can be seen along the glomerular basement membrane (26). Otherwise, antibodies may be directed against the basement membrane itself, in which case a linear pattern of immunofluorescence is seen (26). All of our patients on whom immunofluorescent studies were performed exhibited a granular distribution of both IgG and $\mathrm{C}_{3}$ along the glomerular basement membranes with large amounts of fibrin/fibrinogen localized to the crescents, consistent with an immune complex pathogenesis. However, the severity rather than the etiology of the initial insult seems to determine the prognosis. Table 2 shows that in our patients, the more severe the crescent formation, the worse the prognosis. In a recent study, Whitworth et al. (32) correlated the severity of crescent formation with the number of glomeruli involved and related outcome directly to the extent of involvement (32).

Our patients were treated with a number of agents. Only one patient who received heparin therapy progressed to renal failure. Patient 12 was not treated with anticoagulants because he was referred to our division after five weeks of anuria and a course of dialysis. In this regard, our experience is similar to that of Brown et al. (8) in that patients who presented with prolonged oligoanuria tended to progress to terminal renal failure. However, patient 11 in our series survived despite a period of 12 weeks of oliguria. All but one of the patients which received anticoagulant therapy responded with a dramatic increase in urine output. In two cases, the urine output decreased, and serum creatinine began to rise coincident with withdrawal of therapy. Heparin therapy was reinstituted, and urine output increased; warfarin therapy was begun prior to the discontinuation of heparin, and patients continued to receive warfarin for 3 to 6 months. Patient 2 began to have diuresis 8 weeks after completion of a six-week course of anticoagulant therapy. The only other series comparable to this one is that reported by Brown et al. (8) which also utilized heparin in combination with prednisone, azathioprine or cyclophosphamide, and dipyridamole. The results of that study are similar to ours, but neither study has an adequate control group.
In summary, the 13 patients in this series presented as though they have postinfectious acute glomerulonephritis with edema, gross hematuria, and hypertension. Features which distinguished them from the typical AGN patient were the severe anemia, marked azotemia, and, in most of the patients, marked hypergammaglobulinemia. The etiology was most frequently poststreptococcal; three of seven with this etiology progressed to chronic renal failure. However, the severity of the crescent formation, not the etiology, appears to be the most important prognosticator. Heparin therapy was utilized in six patients, five of whom are currently in good health. Since evidence indicates that the prognosis is favorable in patients with less than $20 \%$ of the glomeruli showing crescents (2), these patients should not be exposed to unnecessary and possibly hazardous therapy. However, patients with crescents in greater than $50 \%$ of the glomeruli deserve a trial of anticoagulation. The only exceptions are patients who present with prolonged oligoanuria; for they do not seem to respond to therapy. Only controlled studies which define the severity and extent of crescent formaton will answer the questions of whom to treat and what kind of therapy to use.

\section{REFERENCES AND NOTES}

1. Allen, D. M., Diamond, L. K., and Howell, D. A.: Anaphylactoid purpura in children (Schonlein-Henoch Syndrome). Am. J. Dis. Child. 99: 833 (1960).

2. Anand, S. K.. Trygstad, C. W., Sharma. H. M., and Northway, J. D.: Extracapillary Proliferative Glomerulonephritis in Children. Pediatrics, 56: 434 (1975).

3. Bacani, R. A., Velasquez, F., Kanter, A., Pirani, C. L., and Pollak, V. E.: Rapidly Progressive (Nonstreptococcal) Glomerulonephritis. Ann. Intern. Med., 69 : 463 (1968).

4. Baldwin, D. S., Gluck, M. C., Schacht, R. G., and Galloo, G.: The long term course of poststreptococcal glomerulonephritis. Ann. Intern. Med., 80: 342 (1974).

5. Berlyne, G. M., and Baker, S. B.: Acute anuric glomerulonephritis. Q. J. Med., 33: 105 (1964).

6. Border. W. A., Wilson. C. B., and Dixon, F. J.: Failure of heparin to affect two types of experimental glomerulonephritis in rabbits. Kidney Int.. 8: 140 (1975).

7. Bone, J. M., Valdes, A. J., Germuth, F. G., and Lubowitz, H.: Heparin therapy in antibasement membrane nephritis. Kidney Int.. 8: 72-79 (1975).

8. Brown, C. B., Turner, D., Ogg, C. S., Wilson, D., Cameron, J. S., Changer, C., and Gee, D.: Combined immunosuppression and anticoagulation in rapidly progressive glomerulonephritis. Lancet, 2: 1166 (1974).

9. Brun, C., Gormesen, H., Hilden, T., Iverson, P., and Raashou, F.: Kidney biopsy in acute glomerulonephritis. Acta Med. Scand., 160: 155 (1958).

10. Burkholder, P. M., and Bradford, W. D. Proliferative glomerulonephritis in children. Am. J. Pathol., 56: 432, 1969.

11. Dodge, W. F., Daeschner, C. W., Brennen, J. C., Rosenberg, H. S., Travis, L. B., and Hopps. H.C.: Percutaneous renal biopsy in children. General considerations. Pediatrics 30: 287 (1962)

12. Edelmann, C. M., Greifer, I., and Barnett. H. C.: The nature of kidney disease in children who fail to recover from apparent acute glomerulonephritis. J. Pediatr., 64: 879 (1964).

13. Ellis, A.: Natural history of Bright's disease. Lancet, $l: 1$ (1942).

14. Glassock, R. J.: Clinico-pathologic spectrum and therapeutic strategies in "rapidly progressive" Glomerulonephritis. Proc. Dialysis Transplant Form 109, 1975.

15. Habib, R. Classification anatomique des nephropathies glomerularies. Pedi. Fortbildungskurse, 28: 3 (1970).

16. Habib, R.: In P. Royer, R. Habib, H. Mathie, M. Broyer; Pediatric nephrology. p. 282. (W. B. Saunders Company, Philadelphia, 1974).

17. Habib. R., Kleinknecht, C.. Gubler, M. C.. and Maiz, H. B.: Idiopathic membranoproliferative glomerulonephritis. In P. Kincaid-Smith. T. H. Matthew, E. L. Becker: Glomerulonephritis: Morphology, natural history, and treatment. p. 491 (John Wiley and Sons. New York. 1973).

18. Habib, R., Kleinknecht, C., Gubler, M. C., and Levy, M.: Idiopathic membranoproliferative glomerulonephritis in children. Report of 105 Cases. Clin. Neph.. 1: 194 (1973).

19. Hamburger, Jean, Richet, G., Crosnier, J., Funck-Brentano, J. L., Antoine B., Ducrot, H., Mery, J. P., and de Montera, H.: In: Nephrology. Chapt. 18. p. 649. (W.B. Saunders Company. Philadelphia, 1968).

20. Harrison, C. V., Loughridge. L. W., and Milne, M. D.: Acute oliguric renal failure in acute glomerulonephritis and polyarteritis nodosa. Q. J. Med.. 33: 39 (1964).

21. Heptinstall, R. H., Kissane, J. M.. McCluskey, R. J., and Porter, K. A.: In: Pathology of the kidney, p. 371. (Little, Brown, and Company, Boston, 1974).

22. Herdman, R. C., Edson. J. R., Pickering, R. J., Fish, A. J.. Markers, S., and Good, R. A.: Anticoagulants in renal disease in children. Am. J. Dis. Child., 119: 27,1970 .

23. Kincaid-Smith, P., Saker, B. M., and Fairley, H. F.: Anticoagulants in "irreversible" acute renal failure. Lancet. 2: 136 (1968).

24. Ladefoged, J., Nielson, B., Raashou, F., and Sorensen, A. W. S. Acute anuria due to polyarteritis nodosa. Am. J. Med., 46: 827 (1969).

25. Leonard, C. D.. Nagle, R. B. Striker, G. E., Cutler, R. E., and Scribner, B. H. 
Acute glomerulonephritis with prolonged oliguria. Ann. Intern. Med., 73: 703 (1970).

26. Lewis, E. J., Cavallo, T., Harrington. J. T., and Cotran, R. S.: An immunopathologic study of rapidly progressive glomerulonephritis in the adult. Hum. Pathol.. 2: 85 (1971)

27. Sonsino, E., Nabarra, B, Katzatchkine, M., Hinglais, N., and Kreis, H. Extracap illary proliferative glomerulonephritis, so-called malignant glomerulonephritis. Ad. Neph, 2: 121, (1972).

28. Travis, L. B., Dodge, W. F., Beathard, G. A., Spargo, B. H., Lorentz, W. B. Carvajal. H. F., and Berger, M. Acute glomerulonephritis in children. Clin. Neph., 1: 69 (1973).

29. Urizar, R. E., Tinglof, B., McIntosh, R., Litman, N., Barnett, E., Wilkerson, J. Smith, F., and Vernier, R. L. Immunosuppressive therapy of proliferative glomerulonephritis in children. Am. J. Dis. Child., 118: 411 (1969).
30. Vassalli, P. and McCluskey, R. T. The pathogenic role of fibrin deposition in immunologically induced glomerulonephritis. Ann. N. Y. Acad. Sci., 116: 1052 (1964).

31. Wannamaker, L. W. Differences between streptococcal infections of the throat and of the skin. N. Engl. J. Med., 282: 78 (1970).

32. Whitworth, J. A., Morel-Maroger, L., Mognon, F., and Richet, G. The significance of extracapillary proliferation. Clinicopathological Review of 60 Patients. Nephron, 16: I (1976).

33. Table available from author upon request.

34. Requests for reprints should be addressed to: R. J. Cunningham, III, M.D. Department of Pediatrics, Division of Nephrology. The University of Texas Medical Branch. Galveston, TX 77550 (USA)

35. Received for publication May 8, 1978.

36. Accepted for publication March 21, 1979.

Copyright (c) 1980 International Pediatric Research Foundation. Inc. 